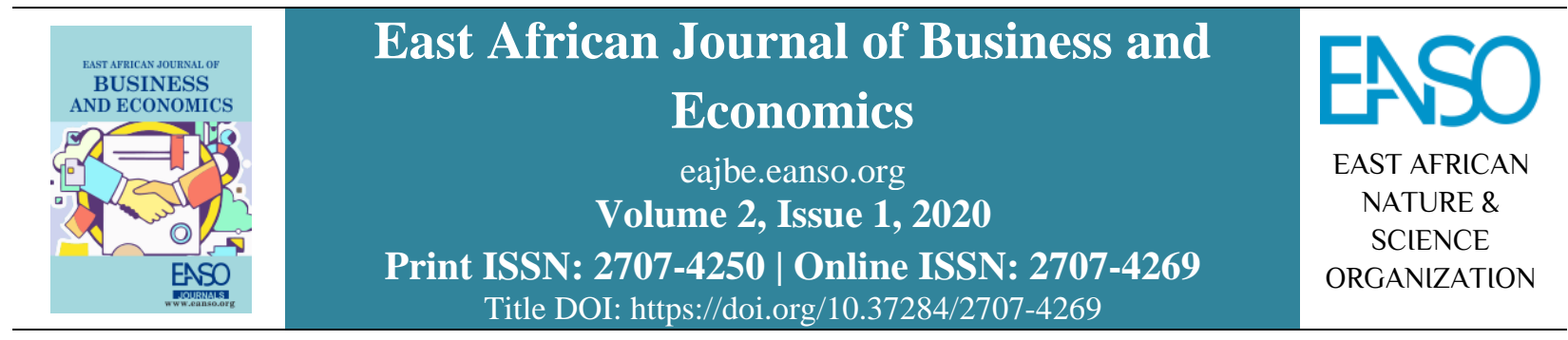

Original Article

\title{
The Contribution of Absolute Income Towards Poverty Reduction in Sub- Saharan Africa: The Case of Rwanda
}

\author{
Dr Kabera Callixte ${ }^{1}$, Dr. Jacob Niyoyita Mahina ${ }^{1} \&$ Dr. Emmy Tushabe ${ }^{1 *}$ \\ ${ }^{1}$ University of Tourism Technology and Business Studies. \\ * Correspondence email: tushabemmy@gmail.com.
}

Article DOI: https://doi.org/10.37284/eajbe.2.1.255

\section{Date Published: ABSTRACT}

14 December 2020 The study portrays current worldwide empirical facts on the progress of economic growth and poverty relief in developing countries of the world. It's

Keywords: well known that in most developing countries, the lives of citizens are not always very pleasant. There are usually lots of inconveniences in the ways of

Poverty Reduction,

Absolute Income,

Sub-Saharan Africa, life for the citizen of these countries. Whenever the government of such a country responds to the inconveniences of life by formulating developmental programs to alleviate the problems of the people, such programs in most cases, do not work, making such government to be frustrated and discouraged. Rwanda. However, the government of Rwanda plays an important role in a number of areas including agriculture, education, and the health sector in order to reduce the mortality rate to its citizens and promote entrepreneurship. The aim of this study is to evaluate the level of absolute poverty and the appropriate methods that Rwanda has applied to curb down poverty levels, at the same time, picking key lessons and guidelines that can be of assistance in curbing down poverty in parts of sub-Saharan countries, Rwanda inclusive. In order to achieve its aim, the paper was put into four sections. Section one explains the poverty profile of Rwanda before and immediately after the genocide while the second part describes the short strategies that Rwanda took to reduce poverty. Section three elaborates the work the country puts to ensure it achieves its goals of achieving long-term goals of becoming a middle-income country by 2020 . The fourth section describes the environment that the state has created to ensure that its strategies work as planned. The research work also relies on other related secondary documents from the mentioned institutions.

APA CITATION

Callixte, K., Mahina, J. N., \& Tushabe, E. (2020). The Contribution of Absolute Income Towards Poverty Reduction in SubSaharan Africa: The Case of Rwanda. East African Journal of Business and Economics, 2(1), 110-117. https://doi.org/10.37284/eajbe.2.1.255 


\section{CHICAGO CITATION}

Callixte, Kabera, Jacob Niyoyita Mahina, and Emmy Tushabe. 2020. "The Contribution of Absolute Income Towards Poverty Reduction in Sub-Saharan Africa: The Case of Rwanda”. East African Journal of Business and Economics 2 (1), $110-117$. https://doi.org/10.37284/eajbe.2.1.255.

\section{HARVARD CITATION}

Callixte, K., Mahina, J. N. and Tushabe, E. (2020) "The Contribution of Absolute Income Towards Poverty Reduction in SubSaharan Africa: The Case of Rwanda”, East African Journal of Business and Economics, 2(1), pp. 110-117. doi: 10.37284/eajbe.2.1.255.

\section{IEEE CITATION}

K. Callixte, J. N. Mahina, and E. Tushabe, "The Contribution of Absolute Income Towards Poverty Reduction in Sub-Saharan Africa: The Case of Rwanda", EAJBE, vol. 2, no. 1, pp. 110-117, Dec. 2020.

\section{MLA CITATION}

Callixte, Kabera, Jacob Niyoyita Mahina, and Emmy Tushabe. "The Contribution of Absolute Income Towards Poverty Reduction in Sub-Saharan Africa: The Case of Rwanda”. East African Journal of Business and Economics, Vol. 2, no. 1, Dec. 2020, pp. 110-117, doi:10.37284/eajbe.2.1.255

\section{INTRODUCTION}

Poverty has been existing and persistent for a long period of time, yet its definition is still not agreed on by many authors. As a result, Poverty definitions exist in a broad range and in different meanings depending on authors and situations. This renders every poverty meaning to be explained by content in relation to poverty beliefs or philosophies, approaches coupled with poverty theories. Western countries dating from the period of World War II, define poverty by measuring the level of income or income power. (Adera et al., 2014). Though we should note that, the economic interpretation of poverty in recent years has been supported by multidimensional mechanisms. For instance, some mechanisms included in the current definition of poverty range from the capability mechanism, the human development mechanism, and the basic need mechanism. Referring to other organisations like the United Nations, it employs approaches like looking at the life expectancy of people, the living standards, levels of education, and purchasing power or ability to consume in order to understand the meaning of poverty. Though, the universal agreed explanation of poverty echoes out circumstances ranging from the economic, social, political, and from other protective circles. Both developing and developed countries have poor people according to the United Nations. Though, some countries have high levels than others. Countries in Sub-Saharan Africa have high poverty levels compared to others.

Sub-Saharan African countries face many forms of poverty with almost all countries stagnation and declining when it comes to economic development. Most Sub-Saharan African countries have low human development index and as per United nations, this 28 of the 31 countries in this region. Sub-Saharan African countries have not seen a drastic reduction in absolute income poverty in the last few decades yet other nations have had progress in terms of poverty relief (McKay, A. 2015). In sub-Saharan Africa, poverty is a changing phenomenon because a section of the population gets in and out of poverty over time and the curve remains negative. Studies show that in Sub-Saharan Africa, poverty is chronic and not transitory and evidence shows that poverty in these countries is a desperately deprived situation and according to the Research Centre describing sixteen countries of the region in a desperately deprived situation. With help from the international community, countries in this region are putting much focus on their assistance to get out of poverty. Although, most countries with the fastest economic growth rates are found in this part of the world.

This paper is intended to evaluate levels of absolute poverty and effective steps that have been used to 
reduce in the country and pick lessons that Rwanda can apply to curb down poverty levels and other countries of sub-Saharan countries. The paper is put in four parts. Part one details Rwanda's poverty profile before and immediately after the genocide, part two describes the short strategies that Rwanda took to reduce poverty. Part three portrays the effort Rwanda has put in place in order to achieve its goals of achieving long-term goals of becoming a middle-income country by 2020 . The fourth section describes the environment that the state has created to ensure that its strategies work as planned. This research work employs a descriptive approach to analysing the level of absolute poverty in Rwanda while both quantitative and qualitative methods of analysis were used to gauge the effectiveness of the poverty reduction strategies. The study uses statistical such as graphs and tables from the Government of Rwanda, United Nations, International Monetary Fund, World Bank, and other relevant sources to extract evidence/data on the effectiveness of the poverty reduction strategies employed by Rwanda. The study also based its work on secondary sources some institutions mentioned above.

\section{THE CASE OF RWANDA}

Referring to the East African region, the smallest country is Rwanda. Worldwide, Rwanda experienced the worst genocide of recent times and over one million Rwandese when the Hutu massacred the Tutsi in a period of three months. (Collier \& Dercon, 2014). Poverty levels are high in Rwanda like any other country in Saharan African. Note that Rwanda's drivers and maintenance of poverty are similar to those of the countries. Political and socio-economical aspects are the movers and maintainers of poverty (Fosu, 2015). In Rwanda, Socio-economic drivers of poverty include increased risks and vulnerability, inequality, limited capabilities, adverse incorporation, exclusion, and limited opportunities and livelihoods (Fosu, 2015). The political maintainers and drivers of poverty revolved around poor governance and corruption. However, Rwanda has taken caution to eliminate the socio-economic and political drivers and maintainers of the absolute income poverty.

\section{Poverty Profile Ten Years After Genocide}

The 1994 genocide had a catastrophic effect on the economy of the already poor nation. Poverty levels drastically increased after the genocide. The World Bank and the International Monetary Fund estimated that over seventy percent of the Rwandese fall below the poverty line in 1997 (McKay, 2015). The depth of poverty also increased after the unfortunate events of 1994. This meant that those who were already poor became poorer. There was little improvement ten years after the genocide. Although the poverty level had reduced between 1994 and 1997, it went up again towards the end of 1997 as the Rwandese population from Congo came back to the country (McKay, 2015). A decade after the genocide, the social-economic indicators of poverty were still very conspicuous. For instance, the period was characterized by an increase in the infant mortality rates from 8.7 to 13.1 percent. High illiteracy levels, high maternal mortality, and poor sanitation also characterized Rwanda of this period (Alinda \& Abbott, 2012). However, the government of Rwanda and the international community had goodwill. The government with the help of the international community set a strategic plan for poverty reduction. This laid a foundation that could be used to eradicate poverty in this country.

\section{RWANDA'S POVERTY REDUCTION STRATEGY}

Based on the Poverty profile of the country, the government saw the need to develop short-term goals that would aid it in poverty alleviation. The first goal was to create an environment that would increase agricultural production and attract better prices for their agricultural output (Collier \& Dercon, 2014). The government also aimed at 
improving the quality of education at the basic levels while at the same increasing accessibility by lowering the cost for the poor. The last government's short-term goal was to provide better health services to its citizens to reduce the mortality rate.

\section{Strategies of Poverty Alleviation Addressing Immediate Agricultural Constraints}

Even before the 1994 genocide, the country's agricultural productivity was already on its decline. The war exposed the country to both conjectural constraints and structural problems that stemmed out from both the genocide and the movement of the population. Ten years after the genocide, the output had recovered by only $78 \%$ of the pregenocide levels (Pritchard, 2013). This meant that the production was too low to cover the needs of the time and generate seasonal savings. The government addressed the constraints in several ways (Alinda \& Abbott, 2012). It first invested heavily in agriculture with an aim of rebuilding its structural capacity that had been destroyed during the war. In this regard, it offered agricultural credits and direct transfers for rural public works (Collier $\&$ Dercon, 2014). It rationalized the restriction on mobility by decreasing the cost of the necessary documentation and the processing speed which increases the community's trading and working capacity. This allowed Rwanda to interact with the rest of the East African community with much. Investors from the East African countries were free to invest in Rwanda's agricultural sector (Alinda \& Abbott, 2012). This provided a platform through which Rwandese learned art agriculture from more advanced countries such as Kenya. Third, Rwanda fasted the allocation of the unoccupied land to those returning from exile. This increased the amount of land available in the country for the cultivation, which resulted in increased food security in the country (Herrero et al., 2014). As the production level increased, the country gained more power to negotiate with traders from other nations.

\section{Improvement of Education}

The schooling cost before the genocide was so high that only a small proportion of the Rwandese would afford it before the genocide. Schools were destroyed due to genocide in the country. It also led to the death and displacement of a large proportion of the teachers and students. After the genocide, the government increased its funding for education. The International Monetary Fund plus the World Bank's contribution and assistance, Rwanda's government was able to narrow down the education cost in the country thus increased the number of people who could afford it (McKay, 2015). The financial help received from the two global organizations also saw Rwanda through the reconstruction of the destroyed schools and the construction of new ones. The government also expanded the teacher training programs and took measures to subsidize other things required for schoolings such as pens, books, and school uniforms. Where necessary, the government hired teachers and education experts from the rest of the world. To date, the number of expatriate teachers working in Rwanda is still high.

\section{Improving Health Care}

The government also took measures to improve healthcare with the realization that it was only when people were healthy that they would work towards the achievement of the national goals (Musafili, 2015). The government increased the funding on health by 110 percent, which helped the health centre provided better services to the citizens. More dispensaries and health centres were constructed. More health care workers were employed. The government also reorganized the redistribution of pharmaceuticals in the country. All this led to improved health care for the Rwandese.

\section{Key Drivers of Poverty Reduction}

The short-term strategic goals were significant in that they helped the country recover from the effect of the genocide by bringing the education, health, 
and agricultural sectors to where they were before the genocide (Adera et al., 2014). Rwanda has made remarkable progress in the last two decades after the short-term goals helped it recover the economic and social fabric of the country destroyed by the genocide. Rwandans have enjoyed reduced poverty, rapid economic growth, increased access to education and health facilities, and more equality and fairness. The government of Rwanda attributes this to the hard work of the Rwandans and the help the country receives from the international community. Like any other Sub-Saharan African countries, Rwanda's government faces the challenge of developing global competitiveness and ensuring self-reliance. Conscious of these challenges, the government launched the Vision 2020 in 2000. Vision 2020 concentrates on using the three most influential sectors of the country's economy to push its poverty reduction goals. In this regard, the government developed a strategy termed the Second Economic and Poverty Reduction Strategy that would help it increase the efficiency of its economic sectors towards the reduction eradication of absolute income poverty.

\section{Agriculture Sector in Rwanda}

Although the short-term goals helped Rwanda recover from the traumatic effects of the genocide, they did not bring the country to the position it would have wanted to be. Important to note is that the government of Rwanda has put strategies in place to reduce poverty. Although, poverty still is high just like in most Sub-Saharan African countries. (Alinda \& Abbott, 2012). This is because the absolute income poverty was extremely high compared to other countries of the region. Towards the achievement of Vision 2020's poverty reduction goals, the government expects the agricultural sector to contribute to the diversification of incomes in a sustainable manner while at the same ensuring the food security of the population is assured (Herrero et al., 2014). To achieve this, the government takes soil conservation measures such as rehabilitation and construction of terraces and also promotes the application of the modern afroforestry technologies that can foster sustainable land use. The governments' 'One Cow 68' program' promotes the ownership of livestock by the Rwandese population (Klapwijk et al., 2014). It is meant to ensure that each poor household in rural Rwanda possesses economically viable livestock including pigs, cows, and goats (Klapwijk et al., 2014). The government also promotes the participation of women in agriculture because, in the traditional Rwandese society, women rarely did farm work. The government also finances more extensive and effective disease control programs (Herrero et al., 2014). Besides, the government of Rwanda offers training services for the farmers and also subsidizes foreign trips for groups of farmers who want to learn some farming strategies in use in other places of the world. Some of the short-term goals on agriculture have also been incorporated in the current poverty reduction strategy (Klapwijk et al., 2014). For instance, the current approach requires the government to offer loans and subsidies to farmers who want to advance farming. To ensure better marketing of Rwandese products in the International market, the government is keen to strengthen farmers' cooperative societies so that they can effectively implement their marketoriented plans towards promoting a marketoriented production by Rwandese farmers. The government of Rwanda is also setting a conducive environment to attract agricultural-based foreign investment in the country.

\section{Manufacturing Sector in Rwanda}

The government of Rwanda sees the manufacturing sector as the most viable engine that can help ensure sustainable economic growth. According to the government, the manufacturing sector should be able to serve as the primary job creator for the other sectors of the economy. The government has taken some measures to ensure that the goods manufactured in the country are competitive. First, the government has and is still creating free export zones and industrial parks to 
enhance the existing manufacturing activities and attract other manufacturers. The government is also promoting the development of new product lines by offering direct incentives to companies that venture into the production of new products. The government is also adopting the export promotion model adopted by most of the very fast-growing economies. However, the government gives more concentration to resource-based manufacturing.

For six years now, the government of Rwanda has tried to enhance the existing low technology industries such as food processing and textile with an aim of promoting labour productivity, product quality, and competitiveness in the COMESA market. The government is also making the entrance into the country's industry less complicated. In addition, it is developing infrastructure at a fast rate with the highest percentage of Rwandan transport and communication systems being up to international standards. This facilitates the activities of the Rwandan industries. Rwanda hopes that its manufacturing sector will play a role in creating numerous jobs in other sectors such as agricultural and service sectors.

\section{The Service Sector}

The government of this East African country also seeks to reduce absolute income poverty by increasing the opportunities in its service sector of the economy. The government is heavily exploiting ways in which to make the best out of the financial services, transport, tourism, and logistic services. Besides, the government is working hard to improve the educational and health services in the country. The government also creates a conducive environment for the financial industry. As such, it has ended attracting several foreign financial institutions to the country. The most notable ones are Kenya-based Equity Bank and the Kenya Commercial Bank (Ndikubwimana \& Berndt, 2015). Financial services are vital to support services to the manufacturing and agricultural sectors. The government is also encouraging investment in education services in Rwanda. Conscious of the fact that it might not be able to provide high education standards, the government is encouraging private investors to invest in education institutions. Although this has been seen by many as a lack of confidence in its education system, the government insists that its bid to attract private investors to the country's education sector is aimed at improving and diversifying the knowledge base of the Rwandese.

Consequently, the government expects that this will increase the employability of the Rwandese in both the local and international markets. The government hopes to use employment creation as the primary method of reducing income poverty in Rwanda. Examples of institutions of higher learning that offer education services to Rwandan citizens include foreign universities from all over the world and especially those from the neighbouring. The government is also investing more in the foreign exchange earnings that can come through tourism. Currently, the tourism sector seconds coffee exports as the highest foreign exchange earner for the country beating tea exports which are in the third position. More specifically, the government of Rwanda is focusing on ecotourism, which includes the natural parks and natural environment (Spencer, Safari \& Dakora, 2014). To achieve its poverty reduction goals of 2020, the government finances the conservation of the natural environment and wildlife, promote monitoring and wildlife research, and engages the local communities in the preservation of the wildlife. It also supports the transport and logistics services through the Ministry of Transport because the two are important in all sectors of the economy.

\section{Facilitator of Poverty Reduction in Rwanda}

As noted earlier, the poverty levels in Rwanda have reduced drastically since 1994, but the absolute income poverty level is still high. However, the government is investing heavily in the 
implementation of the poverty reduction goals of 2020. To complement the strategy and ensure success the government of the country has put efforts to ensure good governance in it. Good governance ensures peace and stability in the country, a good relationship with other countries, and promoting reconciliation among the parties that took part in the genocide (Fosu, 2015).

Rwanda continues to pursue a justice system that upholds the rule of law and human rights while at the same time empowering the people to take part in the economic, social, and political activities with minimal interference from the government (Fosu, 2015). By ensuring political, financial, and administrative accountability, the government of Rwanda has been able to create confidence in the citizens and foreign invests which have laid an excellent platform for poverty reduction (Kwon \& Kim, 2014).

\section{CONCLUSION}

In Rwanda poverty still exists like any other country in Sub-Saharan Africa. However, as this study points out, the coming up of effective strategies might be remarkable to the alleviating of poverty or poverty relief in this part of Africa. As the example of Rwanda portrays, the short-term strategies laid by the country enabled it to recover from the negative effects of genocide to become one of the fasted developing economies in the world. However, Sub-Saharan countries and Rwanda inclusive, become competitive worldwide and self-reliant demands for comprehensive longterm policies and planning. Rwanda implemented Vision 2020 and its operations started in 2001, Rwanda has walked the right path towards alleviating absolute income poverty in the country. Other East African countries in the region, though more developed compared to Rwanda like Kenya have followed the Rwanda journey or route of adopting long-term goals because they have realized that such goals are effective once implemented.

\section{RECOMMENDATIONS}

Based on the review above the following recommendations were made; The paper recommends that the government should explore more creative ways to revitalize the agricultural sector. There should an increase in budget allocation for agriculture to cater for subsidized farm inputs to poor farmers

The government in partnership with NGOs should provide extension services to poor farmers and encourage them to adopt modern ways of doing agriculture such as agribusiness. This will ensure that farmers grow to sell therefore increasing their income. Farmers should also be encouraged to form SACCOs and other social enterprises that will enable them to raise funds to venture into more capital-intensive agribusinesses.

The government should further invest more in education especially in life skills and technical skills. This will ensure that the youths who form the largest part of the population have ready skills to use the acquired skills to earn a living.

This paper finally recommended that apart from the key main drivers of the economy, the government should focus more on the growth of the SME sector to ensure equitable distribution of opportunities through small businesses.

\section{REFERENCES}

Adera, E. O., Waema, T. M., May, J., Mascarenhas, O. \& Giga, K. (Eds). (2014). ICT pathways to poverty reduction: empirical evidence from East and Southern Africa. Ottawa, ON: IDRC.

Alinda, F., \& Abbott, P. (2012). Agricultural policy and institutional framework for the transformation of agriculture, economic development and poverty reduction in Rwanda. Rwanda Public Observatory Report number 6: Institute of Policy Analysis and Research Rwanda. 
Collier, P., \& Dercon, S. (2014). African Agriculture in 50 Years: Smallholders in a Rapidly Changing World?. World Development, 63, 92-101.

Fosu, A. K. (2015). Growth, inequality, and poverty in sub-Saharan Africa: recent progress in a global context. Oxford Development Studies, 43 (1), 44-59.

Herrero, M., Havlik, P., McIntire, J., Palazzo, A., \& Valin, H. (2014). African Livestock Futures: Realizing the potential of livestock for food security, poverty reduction and the environment in Sub-Saharan Africa. Geneva, Switzerland: Office of the Special Representative of the UN Secretary General for Food Security and Nutrition and the United Nations System Influenza Coordination (UNSIC).

Klapwijk, C. J., Bucagu, C., van Wijk, M. T., Udo, H. M. J., Vanlauwe, B., Munyanziza, E., \& Giller, K. E. (2014). The 'One cow per poor family programme: Current and potential fodder availability within smallholder farming systems in southwest Rwanda. Agricultural Systems, $131,11-22$.

Kwon, H. J., \& Kim, E. (2014). Poverty reduction and good governance: Examining the rationale of the Millennium Development Goals. Development and Change, 45 (2), 353-375.

McKay, A. (2015). The recent evolution of consumption poverty in Rwanda. WIDER Working Paper, No. 2015/125. Helsinki, Finland: The United Nations University World Institute for Development Economics Research (UNU-WIDER).

Musafili, A., Essén, B., Baribwira, C., Binagwaho, A., Persson, L. Å., \& Selling, K. E. (2015). Trends and social differentials in child mortality in Rwanda 1990-2010: results from three demographic and health surveys. Journal of
Epidemiology and Community Health, 69 (9), 834-840.

Ndikubwimana, P., \& Berndt, A. (2015). Financial service and customer satisfaction in commercial banks in Rwanda (Bank of Kigali). In 1st Annual Eastern Africa Business and Economic Watch Conference. Finance and Management Research in Eastern Africa Kigali, Rwanda. 5-7 May 2015.

Pritchard, M. F. (2013). Land, power and peace: Tenure formalization, agricultural reform, and livelihood insecurity in rural Rwanda. Land use policy, 30 (1), 186-196.

Spencer, J. P., Safari, E., \& Dakora, E. A. (2014). An evaluation of the tourism value-chain as an alternative to socio-economic development in Rwanda, African tourism. African Journal for Physical Health Education, Recreation and Dance, 20(Issue-21), 569-583. 